\title{
The Reformation of Death in Italy and England, circa 1550
}

Résumé : La présente étude comparative traite des pratiques et des attentes des premiers Protestants à l'égard du lit de mort. L'histoire populaire italienne de la mort de Francesco Spiera en 1548, qui servait de propagande, est comparée avec des textes contemporains de la réforme anglaise. Les prières anglaises autour du lit de mort furent plus éloquentes, mais il y a dans les deux pays des indications d'incertitude en ce qui concerne la dernière communion et la vie future. L'Ars Moriendi du Moyen Âge exerça une influence continue, les réformateurs mettant l'accent sur la mort comme instrument d'apprentissage pour le vivants.

In Samuel Richardson's novel, Clarissa, published in 1747-48, the heroine lcannot escape from her tyrannical family. Even when she is living apart from them, she receives this sinister package of books:

A Drexelius on Eternity, the good old Practice of Piety and a Francis Spira. My brother's wit I suppose. He thinks he does well to point out death and despair to me. ${ }^{1}$

She recognises the three books and the sender's intention with ease: death is being used as a way of controlling the living. Yet, by then, all three titles were well over a century old. The Considerations ... upon Eternity of the Jesuit, Drexelius, and Lewis Bayly's Practise of Piety were popular with English Protestant readers. ${ }^{2}$ The last, the principal focus of this study, was the oldest. Francesco Spiera's final illness took place in Padua in 1548. Nearly two centuries later he appeared on Clarissa's enforced reading list. The Spiera legend had been frequently reproduced and revised and was still embedded in English Protestant psychology. ${ }^{3}$ 
The Spiera story is an uneasy mixture of fact and fiction. It runs like this: Spiera, a hard-up lawyer, took up Protestant beliefs and was questioned by the Venetian Inquisition in 1547-48. He recanted his Protestantism, did a public penance and then fell into incurable despair, from which he died at the end of 1548, convinced that he was damned because he had denied his faith. There can be no doubt about the story's impact. At least three different versions were in print in Latin, Italian and English and circulating widely within two years of Spiera's death. Matteo Gribaldi published his Historia in 1549; it was translated into English in the following year. Also in 1550, at Basel, Caelio Secundo Curione brought out a collection of four supposedly eye-witness accounts, which included a preface by John Calvin. Pier Paolo Vergerio's La Historia di M F. Spiera, printed in 1551, again in Basel, was part of his unrelenting campaign against Cardinal Reginald Pole's alleged concealment of Protestant sympathies. ${ }^{4}$ Spiera's death was a key element in the vociferous European anti-Nicodemite propaganda warfare designed to prevent Protestant dissimulation. "Don't deny your faith" was the intended message, but a death was its context.

To date, historians have concentrated on the propaganda and by-passed the details of the death. This study reverses that process and focusses on what was going on round the death-bed: the conversations, prayers and rituals. These were the activities that Spiera's chroniclers took for granted, and therefore they are an invaluable source of unwitting testimony. Here is a deathbed scene as envisaged by sixteenth-century Italian Protestants. It throws light on some important questions. How did these scattered Italian Protestants expect to reform Catholic practice? What did they do and what did they believe about death? How did their expectations and beliefs compare with those of other Protestants? Contemporary English death rituals will be used for this comparison. The Italian-English link is useful for two reasons. First, the Edwardian reformation provided plenty of evidence exactly contemporary with the Spiera publications. Second, English readers knew all about Spiera - and were encouraged to die better than he had. ${ }^{5}$ This study asks whether there were enough similarities between the rituals at Spiera's deathbed and contemporary English evidence to suggest that these Protestants were in broad agreement about the reformation of deathbed practices.

European Christendom already had a Catholic construct of death, known to both literate and illiterate. Spiera's tragedians wrote very close in time to the highpoint of the Ars Moriendi. The text, Speculum artis bene moriendi, first appeared in the early fifteenth century, but the related publications in the second half of the century of eleven woodcut pictures with brief textual explanations gave it a powerful hold on the popular imagination in Italy and 
England as elsewhere. ${ }^{6}$ Spiera's story was closely modelled on the Ars Moriendi. Many components are the same: a dying man as the centre of attention in a crowded room, a clergyman to visit and guide, family and friends around, the involvement of lawyers and doctors, the presence of devils, ritual acts. The Catholic bits have been taken out and the outcome was radically different. Moriens of the old texts had some despairing moments but finally died well. Spiera died very badly.

Some historians have treated the Spiera stories as fact. This is unwise. We are in the field of anti-Nicodemite propaganda. The accounts do not agree and are so highly stylised that it is clear that the writers are fitting real events into archetypal patterns. ${ }^{7}$ Similarly, all the writers were or became Protestants and glossed events according to the denominational certainties of later generations. But these hard and fast lines were not so clear in the doctrinal fog of Northern Italy in the late 1540s. Spiera had certainly toyed with ideas later viewed as Protestant, but so had many eminent Catholics. At the time of his imprisonment in 1556, Cardinal Morone wistfully reflected upon the situation in Italy a decade earlier, which had brought such trouble on his head, as on Spiera's: "There was very nearly licence for everyone to do and say what he thought right." 8 Spiera's drama began in the same atmosphere of theological free-for-all. But in the Veneto region, where he lived, the rules of the game changed suddenly in 1547. In January, the Decree of Justification was issued from Trent, and in the April of that year the Roman Inquisition was permitted for the first time in Venice, a permission granted reluctantly by a state always deeply resistant to the papacy. It was powerless nonentities like Spiera who were the first to be caught in the shifting political sands. ${ }^{9}$

Spiera was a notary. He would have visited many sickrooms, and it is clear that death was much on his mind from the outset of his examination by the ecclesiastical authorities. When his Inquisition trial began in May 1548, he admitted doubts on Purgatory and on the suffering of the dead, based on his faith that Christ had died for his sins. He also agreed that he had a Bible, had translated the Lord's Prayer and had read the Beneficio di Cristo. He was told to abjure, and soon afterwards despair set in and a serious illness was diagnosed. ${ }^{10} \mathrm{He}$ was so ill that he was moved from Cittadella, his home, to Padua for medical treatment, and it was there that all the writers of the deathbed accounts visited him. They make it clear that, by then, Spiera was a very sick man, kept alive by force-feeding. His mental state is harder to fathom. According to Matteo Gribaldi, Spiera was "looking every hour for the terrible sentence of God." "Yet in Gribaldi's and all the other Protestant accounts, he was presented as dignified, reflective, well-versed in his faith and in the Scripture and, in the early stages, co-operative about everything 
except food. Protestants stressed his absolute sanity, while every Catholic deposition to the Inquisition after Spiera's death said he was mad. ${ }^{12}$

The writers of the main accounts were part of a rather classy team of professional visitors: a professor of law, two other lawyers, several doctors, a bishop and at least one parish priest - in some accounts more. The professor was Matteo Gribaldi, already a Protestant, working in Padua but officially resident, for reasons of safety, in Protestant Basel. The bishop was Pier Paolo Vergerio, a friend of Gribaldi, still a Catholic, but being watched by the Inquisition when the Spiera saga started. By his own account he visited about twenty times, and the local bishop certainly objected to his obsessive interest. From his exile two years later, Vergerio told Martin Borrhaus, "I would not be in Basel now had I not seen Spiera."13

But without Vergerio, Spiera probably would not be with us either. $\mathrm{He}$ inserted Spiera's death into the anti-Nicodemite campaign, and his version of events influenced all the other writers: they quoted his testimony and deferred to him a great deal. Although Spiera turned away from a local priest, Antonio Fontanina, who was involved with his recantation, there was no general anti-clericalism. Everyone wanted Vergerio's advice about what to do and when to pray. He was master of ceremonies, as well as chief chronicler at this notorious death. ${ }^{14}$

It was a social deathbed; often there were thirty people there at once a scene very much in accordance with Catholic traditions. The fifth chapter of the textual version of the Ars Moriendi says that neighbours should help Moriens repent and be reconciled, and that they should read spiritual books to him. Above all, they should pray. ${ }^{15}$ Spiera's neighbours have different priorities. They do not seem to pray much on their own initiative - only when Vergerio leads them. They talk theology, quote Scripture and discuss doctrine a great deal. On the faith-versus-works issue they are particularly vocal. Many of them are "young men," probably students at the University of Padua. ${ }^{16}$ Their role, especially in Gribaldi's account, is one of the most arresting features of these documents; a theological seminar rumbles on around the deathbed. Neighbours and students alike are there to learn. Ariès has noted how, from the sixteenth century onwards, the "ars moriendi" changed to the "ars vivendi," and that is certainly what seems to be going on here. ${ }^{17}$

Demons are present - left there at deathbeds, of course, by medieval literature and iconography - but it is significant that they are carried into Protestant death so completely. Thus, Spiera sees a fly and thinks it is Beelzebub; later, "weeping [he] began to declare unto to us horrible visions. He perceived devils to come to his chamber, yea to his bed, making a noise 
and business. ... sticking pins in the pillow. ... and ... he conceived not these things by a false or corrupt imagination." 18 This was certainly not original: the Ars Moriendi's woodcut for the moment of despair also has a devil perilously close to the pillow. ${ }^{19}$ Such mental types transcended theological divisions.

Profession of faith was a crucial first step in deathbed ritual in both the Ars Moriendi and the Spiera accounts. The Ars includes alternatives for this profession - one quite a slick credal statement, the other more ponderous and detailed. ${ }^{20}$ But when Spiera's visitors ask him about his faith, they seem to want something different - something more like a full personal testament: when he started to believe, what he thinks are the essentials and why he has lost faith. He begins by saying that he believes "in the infinite mercy of god, that every man who has faith obtaineth pardon of all the sins of the world" but wearily points out that he lacks this faith, hence his condition. ${ }^{21}$ On their second visit, Vergerio and Gribaldi question him further about his old faith, and his answer is long and specific and packed with scriptural quotation. The formal statements which had characterised Catholic death literature have been superseded. The spontaneous declaration of individual faith is being pushed up the scale of importance.

There is such a contradiction between Protestant and Catholic evidence on the issue of Spiera's confession and communion that it is impossible for the historian to decide whether he received either sacrament. Nardini, the relative with whom Spiera stayed in Padua, was brought before the Inquisition two weeks after Spiera's death to give an account of what had happened. Relatives in such tricky situations have their own axes to grind, so his carefully Catholic evidence is just as unreliable as that of the Protestant writers. Nardini said that Vergerio had paid for the services of a doctor, Pietro di Crassio, "because of his situation, to get him to confession and communion."22 A Protestant source, the writer of a letter included in Curio's collection of Spiera narratives, said that communion was offered but that Spiera refused it on the grounds that "he would therefore receive it to his own damnation because had not faith." 23 Yet the main sources, Vergerio and Gribaldi, excluded all mention of the last sacraments altogether. The conflict of evidence suggests a sensitive topic.

So, to the matter of confession - a practice not rejected outright by all Protestant reformers. ${ }^{24}$ Spiera's chroniclers make much of his two public self-accusations. In Vergerio's account, Spiera tells of his "sin which he had committed in the exercise of his authority as a lawyer" and then of his "denial."25 But in Gribaldi's account, different sins crop up: "I did not reknowledge the benefits of Christ. . . . But rather I took the faith of the 
gospel to the liberty of the flesh and so did abuse that faith to unlawful licence to sin." Then Spiera launches into a lengthy piece of advice interspersed with self-accusation. It is directed at a group of young men standing at the bedside:

Ye should not set too much by your faith, but that also ye should do good workes ... he did commend, above all the scripture, the worthy epistle of peter which exhorteth all Christians to godliness, holiness, chastitie and a cleane life ... but I lived wickedly and ungodly. ${ }^{26}$

Tantalizingly vague as it is, the bystanders seem to treat this as a form of confession: "Then began we to dispute the matter ... and diligently to search whether his trespass were mortal or no." 27 Clearly, this was not sacramental confession. But, as the latter went out the back door, a very public form of self-accusation seemed to be coming in the front. Protestants were still acting out confessional roles and using the traditional categories of $\sin -$ is it mortal?

The very silence on the subject of communion in the main accounts prompts further questions about the reason for the presence of so many clergymen. Had these priests and their accompanying bishop hoped to offer a sacrament Spiera refused? Or had they come as proto-Protestants, determined to find a non-sacramental but still clerical function? Certainly, it is Vergerio to whom everyone looks to lead the prayers, and prayer itself is still definitely an important part of the deathbed scene. But these Italian reformers seem at a loss for words; they use the Lord's Prayer and nothing but the Lord's Prayer. There is none of the confident patchworking seen in many reformation liturgies. Even their prayer is not a disinterestedly spiritual activity; it is used to gauge Spiera's spiritual state. Three times Vergerio tried to get Spiera to say the Lord's Prayer, changing the language from Italian to Latin as the general anxiety increased. Whilst he did this, the bystanders watched for signs of Spiera's disposition. So after Vergerio's "I would we prayed together," Spiera said the "Our Father, in his mother tongue. . . . with such gravity and devotion" that all were impressed. Later, when Spiera has told of visions of devils, Vergerio suggests the Lord's Prayer in Latin and Spiera responds, "with plentiful tears devoutly and gravely." At their third shot, the language is unspecified, and "he said it no more with such affection of heart." 28

It seems clear that Spiera's emotions are under such intense scrutiny because these bystanders are on the look-out for signs of election or reprobation. What is going on inside heart and head is seen as crucial, as Spiera himself recognises: "I have said it with my mouth but my heart is clean from it." 29 His luke-warm prayer and his increasing fierceness towards friends 
and family are bad signs. His weeping, however, is a good one, and at that moment Gribaldi bursts out, "Now Master Francis, the blessed God be praised, now these are not the tokens of utter refusing or casting away." 30

When Spiera himself quashes such hopes, the spectators try new tacks. Perhaps Spiera is "so tormented in this world that God hath not reserved your punishment to another world." This idea imitates the redemptive suffering of Lazarus and is far closer to salvation by works than by faith. Spiera's learned visitors had all been trained as lawyers, not theologians, and they seem far from sure of themselves. Several theologies of death are running at once. Later Gribaldi tries "the sleeping of souls," an ancient belief which had been revived by Luther. ${ }^{31}$ Spiera's reply, however, sidelines Luther and goes straight back to predestination: "Although a certain doctor of Germany supposeth that this is not manifestly enough declared by the scriptures; yet I believe that the soul of the elect doth straight way ascend unto the place of everlasting bliss and doth not sleep with the buried body." 32

Other theologies of death had been aired, but predestination had won. ${ }^{33}$ Finally, the writers show that Spiera is not going to "everlasting bliss." Conclusive proof of his state of soul emerges when he threatens suicide and snatches at "wood-knives" and "cords." Calvin wrote a preface insisting that Spiera actually succeeded in strangling himself, but the artful Italian chroniclers were more subtle. Although they wrote after Spiera's death, they ended their stories at the moment when Spiera was taken from Padua on a carriage to travel the short journey home to Cittadella to die. Disingenuously, they pretended not to know the outcome, and, in their epilogues, they asked their readers for news of him. ${ }^{34}$

This, the very opposite of a good death, sheds some light on what kind of reconstruction of death was going on among Italian Protestants. The similarities to the Ars Moriendi suggest that its influence was a pervasive, if unconscious, model, always lurking in the background. The sickroom was crowded with neighbours (perhaps more so than that of Moriens), but these Protestant visitors discussed issues of faith more than they interceded. Instruction of the bystanders is a major preoccupation of all the versions of the story. The relationships, emotions and dispositions were closely watched as signs of the state of mind and therefore of the ultimate destination of the dying. Professionals, such as clergymen, doctors and lawyers, still visited frequently, and so did "cohorts of devils." 35 It was still the doctor's role to say when it was time for the final rituals. The last sacraments were the subject of some contradiction. Unction has gone. Sacramental confession and absolution have been replaced by self-accusation by innuendo. Communion was offered, according to some witnesses, but the main Protestant accounts 
pointedly omit it. The clergyman's role was no longer sacramental, but he was still expected to lead the prayers. These, however, seemed to consist of nothing but the Lord's Prayer. As 'to beliefs about life after death, the dominant theology was predestinarian; but other ideas about how the dying might be saved were still under discussion.

But the Italian Reformation is often seen as half-born, radical, eccentric. ${ }^{36}$ Did these goings-on in Spiera's sickroom bear any relation to the expectations of other Protestants? Were English Protestant deathbeds enough like Spiera's to suggest a developing European Protestant art of dying? My main points of comparison will be Thomas Becon's Sicke Mans Salve, a guide to a good Protestant death in dramatic form, probably written in 1553, and the two Edwardian Prayer Books of 1549 and 1552. 37

Just as the entire Spiera story was written to scare the living, so all the English sources show the same shift from "Moriens" to the bystanders. Becon's four comforters (shades of Job?) have the effrontery to express their self-interest, as the sick man, Epaphroditus, reaches his death throes: "In you as in a cleare mirror we:behold ourselves and see what shall become of us hereafter. In you as of a lively schoolmaster do we learne." 38 Such learning had become central to Protestantism. Since the foundations of faith had been shaken, they had to be rebuilt, and this, the most important of all the rites of passage, was too good a chance to be missed. So theological teaching had priority in English sickrooms, as in Spiera's. "Dearly Beloved, know this ..." are the first words the priest-cum-minister addresses to the sick in the Visitation rite in both Prayer Books. ${ }^{39}$

Similarly, the intense scripturalism of the Spiera pieces is mirrored in England. Becon's commentary on the Nicene Creed, supposedly delivered at the bedside, added so many scriptural proofs that his version runs to 4000 words. Both Prayer Books turn prayer itself into a vehicle for scriptural teaching, usually to remind God of his own good record: "Visit him as thou didst visit Peter's wife's mother and the Captain's servant. And as thou preservdst Thobie and Sara by thy angel from danger: So restore this sick person to his former health." 40 Becon does the same: "Deliver him, O Lord, as thou deliveredst Noe from the raging waves of the sea. Lot from the destruction of Sodom, Abraham from the fear of the Chaldes, the children of Israel fron the tiranny of pharao, David from the hand of Goliath. ... "41 Here the list is, in fact, very long indeed. Whereas the Ars Moriendi had suggested that visiting neighbours should read his favourite spiritual books to the dying man, Protestantism was "single source." 42 .That source, the scriptures, bounced off the walls of sickrooms in England, as in Italy. 
English sources, however, move towards a devotional variety missing at Spiera's deathbed. Apart from the weaving of Scripture into prayer, there was more willingness to raid the Catholic traditions. The rites for the visitation of the sick continue to use the Psalms as an introduction, and there is the old "Saviour of the world" prayer at the end. Becon's sick man even has a shortened "Commendatio," the ancient "Go forth, O Christian soul ...," at the moment of death. This dipping into Catholic liturgy seems to have made the English less tongue-tied in face of death. ${ }^{43}$

Sickrooms in England, as in Italy, remained the territory of the professionals, and especially of the clergy. They were in charge of this reconstruction, and it was inherently unlikely that they would write themselves out of the script. English parish records, too, show that people wanted them there and were scandalised by their absence or refusal. ${ }^{44}$ Neighbours gathered in English deathbed scenes to the same degree as in Spiera's. Becon's dramatic form made it inevitable that his four visitors should be even more of a chat-show than Spiera's theologising students. ${ }^{45}$ But both Prayer Books recognised the potential usefulness of bystanders for making practical arrangements, and the uplifted neighbourly hands of Tudor death pictures prove prayer to have been part of their role. ${ }^{46}$ Spectators had always been important, but Protestantism raised their stock significantly.

Visitation from "the cohorts of devils" was regarded as a fact of death in England, as in Italy: Becon thought them "most Busy" at that time. ${ }^{47}$ Whereas Spiera had them on his pillow, a young Cambridge undergraduate sited them at the end of his bed, where he could spit at them. Medieval iconography had left them jostling for position on, under, behind and above deathbeds, and there they stayed ${ }^{48}$

English evidence, like the Italian, contains, suspicious contradictions regarding the sacraments. Becon excludes them altogether and specifically mocks "Communions-saying" among other "worthless" traditions. ${ }^{49}$ For confession, he substitutes a generalised public self-accusation, very like Spiera's. ${ }^{50}$ But the evidence of the Prayer Books is significantly more sacramental, and this is true even of the 1552 book, which was, in MacCulloch's telling phrase, "a piece of theological hatchet-work" so far as death was concerned. ${ }^{51}$ Unction disappeared altogether, as did all possibility of taking the consecrated and reserved host to the sick. Yet, even after that radical pruning, private confession was possible, if desired, and the words of absolution were not altered. What is more, the communion of the sick remained - although in practice it became distinctly harder to get. The rubric concerning practical preparations goes like this: 
The sick person ... must give knowledge overnight, or else early in the morning to the Curate, signifying also how many be appointed to communicate with him. And having a convenient place in the sick man's house, where the curate may reverently minister, and a good number to receive communion with the sick person, with all things necessary for the same, he shall there minister the Holy Communion. ${ }^{52}$

This required management. The English generation which had grown up with the medieval horror of dying "unshriven" and "unhouseled" was allowed to keep both sacraments, but only if they could make all the right arrangements in time. ${ }^{53}$ All the "ifs" and "buts" were powerful messengers of a changed set of priorities.

The state of mind of Moriens at the final moment remained paramount. ${ }^{54}$ The English scrutinised the emotions and then interpreted the signs just as intensively as in the Spiera accounts. It mattered that death was well taken by the dying. He or she must show a proper sense of providence: "know you certainly that it is God's visitation." "Submitting yourself" required that there should be no grumbling, some weeping and much faith. ${ }^{55}$ These dispositions had left the stage as Catholic good works and returned immediately as Protestant signs of election. Despair, too, remained a compulsory experience. Becon's well-behaved Protestant still has a very lengthy slough of despond. ${ }^{56}$ Theologies might come and go but despair endured. If it continued too close to the point of death, however, that was bad news and of itself an indication of damnation. Re-enter Spiera.

His creators were responsible for a daring distortion of tradition. The impenetrable despair of the Italian accounts was not what the English envisaged. It is significant that Latimer took issue with their theology in the same breath as he mentioned Spiera, in a sermon before Edward VI's court in 1552:

I know that Judas sinned against the Holy Ghost, also Nero, Pharoah and one Franciscus Spira; Which man had forsaken popery ... [but] he, contrary to the admonition of the Holy Ghost, denied the word of God and so finally died in desperation; him I may pronounce to have sinned against the Holy Ghost. But I will show you a remedy for sin against the Holy Ghost. Ask remission of sin in the name of Christ and then I ascertain you that you sin not against the Holy Ghost. ${ }^{57}$

Latimer's "remedy" was tantamount to a bucket of cold water. Despair was all well and good but persistence in it was unchristian. Nonetheless, the tale of Spiera's nasty death was devoured by English readers. It influenced Nathaniel Woodes, Christopher Marlowe, then John Bunyan, and from there found fame in English and Scottish chap-books until well into the nineteenth century, terrifying the uneducated in the process. ${ }^{58}$ But even though this later literature absorbed Spiera's message that people could be damned and go to 
hell, mid-sixteenth century English sermons, deathbed guides and official liturgies certainly did not.

So where were the English going? Social historians often argue that since Protestants gave up purgatory and thought the decision about Heaven or Hell happened immediately, the Reformation involved a revolution in deathbed practice. But this view seems to interpret the sixteenth century situation in the light of the more settled views of seventeenth century predestinarians. ${ }^{59}$ These doctrines had not bedded down by the middle of the sixteenth century. English sources, quite as much as the Italian, suggest that there was an interim, a time to come to terms with contradictory views about the destination of the dying. As late as 1550, Latimer was still praying for souls. Becon thundered against the "purgatorirakers," but belief in purgatory was so hard to shift that Sandys still saw a need to preach against it in 1574.60 Also, the ancient idea of the sleep of death influenced this English generation schooled in the classics and sometimes in Luther's writings. Preachers regularly called cemeteries "dormitories of Christians." Like the Italians, the English were still finding their way on this sensitive subject, even though predestination was to be accepted gradually as orthodoxy. ${ }^{61}$

Consolation pervaded official English sources. Cranmer's "Homily on the Fear of Death" ends on an unequivocal note: "Wherefore it cannot but be that if we be his faithful servants, our souls shall be with him after our departing."62 The idea of damnation crops up in the Prayer Book liturgies in the context of a gospel reading and appears only as something that will be avoided: "he that heareth my word . . . shall not come into damnation." Article 17 on Predestination of the 42 Articles of 1553 is the classic instance of teaching election but leaving reprobation unsaid. The words of committal in the Burial Service in both the 1549 and 1552 Prayer Books - "in sure and certain hope of resurrection to eternal life" 63 - resounded at life's most tender moment, despite later predestinarian protests. Private sources suggest that good Calvinists believed that their relatives and friends were going to Heaven. ${ }^{64}$ The Spiera narratives were propaganda; they were bound to collide with liturgy and pastoral practice on this final, crucial point. Their message was one man's hell, whereas the entire "elect nation" seemed likely to avoid such an outcome.

In all other respects, however, there are strong similarities between these two Protestant reconstructions: doctrinal teaching and scriptural quotation in the sickroom, apparently aimed at the living rather than the dying; theologically minded and talkative visitors; attempts to find new words for bedside prayer, halting in Italy, bolder in England; public but non-specific confessions of sin; contradictions, sensitivities, "ifs" and "buts" about the 
last communion; intense concentration on the emotions of the dying man and his dispositions at the last moment; unsettled doctrines of the hereafter. Italian and English Protestants were reforming death on very similar lines, and both were weaving Protestant variations around the Ars Moriendi's persistent theme.

Open University

\section{Notes}

1. Samuel Richardson, Clarissa; or the History of a Young Lady, Everyman's Library, 4 vols. (London: Dent, 1965-67.), 2: 256, 262 (Letter 74,.Clarissa to Miss Howe).

2. Hieremias Drexelius (Jeremiah Drexel), De Aeternitate Considerationes (1620), trans. R. Winterton as The Considerations of Drexelius upon Eternity (London: N. Alsop, 1632), RSTC 7235; Lewis Bayly, The Practise of Pietie (London: J. Hodges, 1612), RSTC 1601.5.

3. The best-known English version of the story of Francesco Spiera is Nathaniel Bacon's $A$ Relation of the Fearful Estate of Francis Spira, published in London in 1638 and in multiple editions thereafter (RSTC $1177.5 \mathrm{ff}$.). This also formed the basis of shortened versions of the story subsequently widely issued as chap-books, for instance, An awful memorial of the state of Francis Spira after he turned apostate from the Protestant Church to Popery (Falkirk: T. Johnson, 1815). Alexandra Walsham shows the tenacity and effects of the Spiera myth in England (Providence in Early Modern England [Oxford: Oxford University Press, 1999], pp. 86, 326-27).

4. Matteo Gribaldi, Historia de quodam [F. Spira] quem hostes Evangelii in Italia coegerunt abiicere cognitam veritatem (Padua, 1549); the place of publication is false. The English translation that followed immediately was entitled $A$ Notable and Marvailous Epistle, trans. E. A. [Edward Aglionby] (Worcester: J. Oswen, 1550), RSTC. 12365. All subsequent references to Gribaldi will be to this version. Next from the continental presses was a collection of accounts edited by Caelio Secundo Curione: Francisci Spierae qui quod susceptam semel Evangelicae veritatis professionem abnegasset (Basel, 1550). This includes pieces by Gribaldi, Pier Paolo Vergerio, Sigismund Gelous "from Transylvania" and Henry Scrymgeour, a Scottish Protestant from St. Andrews. Prefaces to the Curio collection are by John Calvin and Martin Borrhaus, and there are also six letters purporting to be from eye-witnesses. The best-known account was by Vergerio, La historia di $M$. $F$. Spiera, il quale per havere in varii modi negata la conosciuta verita dell'Evangelio casco in una misera desperatione (ed. P. P. Vergerio [Basel, 1551]).

5. Direct influence cannot be proved, but knowledge and impact were immediate. See, for instance, Hugh Latimer, Sermons, ed. George Elwes Corrie, Parker Society, 2 vols. (Cambridge: Cambridge University Press, 1844), 1: 425, and M. A. Overell, "Edwardian Court Humanism and Il Benefico di Cristo," in Reassessing Tudor Humanism, ed. Jonathan Woolfson (Houndmills, Basingstoke, Hampshire: Palgrave, forthcoming). For background on the Italian Reformation, see Sylvana Seidel Menchi, "Italy," in The Reformation in a National Context, ed. Bob Scribner, Roy Porter and Mikuláš Teich (Cambridge: Cambridge University Press, 1994), pp. 181-96; also Euan Cameron, "Italy," in The Early Reformation in Europe, ed. Andrew Pettegree (Cambridge: Cambridge University Press, 1992), pp. 189-212. For the Spiera story in the context of "Renaissance self-fashioning," see John 
Martin, "Inventing Sincerity, Refashioning Prudence: The Discovery of the Individual in Renaissance Europe," American Historical Review 102 (1997): 1309-42, esp. 1321-22.

6. The original, Tractatus or Speculum artis bene moriendi, appeared between 1414 and 1418 and circulated widely in manuscript. The English version is reprinted in The Boke of the Crafte of Dyinge, in Yorkshire Writers: Richard Rolle of Hampole and his Followers, ed. Carl Horstmann (London: Swan Sonnenschein, 1896). The famous abridged version, with woodcuts, usually known as the Ars Moriendi, is in a facsimile edition, Ars Moriendi, editio princeps, circa 1450, a reproduction of the copy in the British Museum, ed. W. H. Rylands (London: Wyman, 1881); see also RSTC 786-92. For detail of Italian and English versions, see Sister Mary Catherine O'Connor, The Art of Dying Well: The Development of the Ars Moriendi (1942; rpt. New York: AMS Press, 1966), pp. 157-67, 178-79. See also Nancy Lee Beaty, The Craft of Dying: A Study in the Literary Tradition of the Ars Moriendi in England (New Haven: Yale University Press, 1970), and David W. Atkinson, "The English ars moriendi: Its Protestant Transformation," Renaissance and Reformation 18.1 (1982): $1-10$.

7. Christopher Hill, A Turbulent, Seditious and Factious People: John Bunyan and His Church (Oxford: Clarendon Press, 1991), p. 185; John Staniewski, The Persecutory Imagination (Oxford: Clarendon Press, 1990), pp. 37-39.

8. Massimo Firpo and Dario Marcatto, eds., Il processo inquisitoriale del cardinal Giovanni Morone (Rome: Instituto storico per l'età moderna e contemporanea, 1981-89), 2: 465. All translations are by the author unless otherwise stated. See also M. A. Overell, "The Exploitation of Francesco Spiera," Sixteenth Century Journal 26 (1995): 619-37, esp. $622 \mathrm{n} 12$.

9. Overell, "Spiera," p. 623.

10. Ibid., p. 625. David Gentilcore's work on contemporary Italian states of mind is a fascinating and relevant study ("The Fear of Disease and the Disease of Fear," in Fear in Early Modern Society, ed. William Naphy and Penny Roberts [Manchester: Manchester University Press, 1997], pp. 184-209).

11. Gribaldi, sig. Bvi.

12. See Vergerio, La Historia, fol. $11^{\mathrm{v}}$; Gribaldi, sig. Aviii; and Nardini's deposition, cited by Giuseppe De Leva, Degli Eretici di Cittadella (Venice: Grimaldo, 1873), p. 39.

13. Vergerio to Martin Borrhaus, 1550, cited De Leva, p. 43: "Ego Borrhae, inquit, hoc tempore Basilae non essem, si Spira non videssem."

14. See M. A. Overell, "Vergerio's Anti-Nicodemite Propaganda and England: 1547-1558," Journal of Ecclesiastical History 52 (2000): 296-318.

15. Eamon Duffy, The Stripping of the Altars: Traditional Religion in England (New Haven: Yale University Press, 1992), pp. 348-54.

16. They may well have been the German Protestant students who were involved with Gribaldi and had protected status at Padua until well into the 1550 s. For the various "nations" of the University of Padua, see Jonathan Woolfson, Padua and the Tudors (Cambridge: James Clarke, 1998), pp. 10-15.

17. Philippe Ariès, The Hour of Our Death, trans. Helen Weaver (London: Penguin Books, 1987), pp. 303-5.

18. Gribaldi, sig. Bii. 
19. "The temptation to despair," reproduced in Duffy (illustration 117). See also Peter Marshall, "Fear, Purgatory and Polemic," in Fear in Early Modern Society, ed. Naphy and Roberts, pp. 150-66, and O'Connor, pp. 178-79.

20. Interestingly, these involved rejection of the idea that salvation could be earned (Beaty, p. 21).

21. Gribaldi, sig. Biv-v.

22. Cited De Leva, p. 45. The account of Sigismund Gelous in Curio's collection confirms that three doctors were sent to Spiera, one of whom was Pietro Crassio (Curio, p. 106). In medieval popular belief, reception of the last rites meant abstinence from life's pleasures, including sex, even if recovery followed. This was not orthodox teaching but widely believed. So the sick man usually waited for the doctor to confirm that there was no hope of recovery and the time had come for the last sacraments.

23. Curio, p. 24 (Letter 1).

24. See Thomas N. Tentler, Sin and Confession on the Eve of the Reformation (Princeton: Princeton University Press, 1977), pp. 349-62; Lawrence Duggan, "Fear and Confession on the Eve of the Reformation," Archiv für Reformationsgeschichte 75 (1984): 153-75; and David Myers, "Ritual, Confession and Religion in Sixteenth Century Germany," Archiv für Reformationsgeschichte 89 (1998): 125-43.

25. "si doleva de peccati che esso haveva fatto con l'esercitio dell' avocateria.... Ho commesso il peccato della negatione" (Vergerio, fol. $10^{v}-11$ ). Nardini told the Inquisition that Spiera's"cupidity" as a lawyer was the cause of his despair, rather than his denial of faith (Overell, "Spiera," p. 625).

26. Gribaldi, sig. Bvii-viii. The phrase "the benefit of Christ," much used in Italian Reformation works, formed the title of its most famous book, Il Beneficio di Cristo (Venice, 1543), which Spiera told the Inquisition that he had read (Salvatore Caponetto, La Riforma protestante nell'Italia del Cinquecento [Turin: Claudiane, 1992], pp. 63-64).

27. Gribaldi; sig. Bix-Ci.

28. Gribaldi, sig. Bii. Christian literature contains many instances of "three times" passages like this one, from the story of Gethsemene onwards. Spiera's biographers are clearly working to a pattern rather than recording events.

29. Gribaldi, sig. Bii. For a psychological approach, see Michael MacDonald, "The Fearful Estate of Francis Spira': Narrative, Identity and Emotion in Early Modern England," Journal of British Studies 31 (1992): 32-61.

30. Gribaldi, sig. Biiii. "The hands and faces of his children were as horrible to him as the hangman," according to Scrymgeour's account, adapted in Simon Goulart, Admirable and Memorable Histories, trans. E. Grimeston (London, 1607), p. 189.

31. The "refrigerium," the "waiting" of the dead, was found in ancient belief and had been adapted by Luther, but was frowned on by most other Protestants (Ariès, pp. 147-48).

32. Gribaldi, sig. Cii.

33. For the development of predestinarian thought amongst Italian reformers, see Frank James III, Peter Martyr Vermigli and Predestination: The Augustinian Inheritance of an Italian Reformer (Oxford: Oxford University Press, 1998), pp. 164-85.

34. Richard Wunderli and Gerald Broce, "The Final Moment before Death in Early Modern England," Sixteenth Century Journal 20 (1989): 259-75. Calvin's preface to Gribaldi's 
account says, succinctly, "he strangled himself" (Gribaldi, sig. Aiiii). I know of no other evidence to support this confident summary. Calvin's dislike of Italians in general and Italian Nicodemites in particular makes him a prejudiced witness on this point. According to Gribaldi's own account, Spiera "espied a woodknife, lying upon the table which, by and by, he snatched to sticke himself" (Gribaldi, sigs. Ciii-Ciiij). The dagger and the cord are part of the traditional emblematics of despair.

35. Curio, p. 7.

36. Dermot Fenlon, Heresy and Obedience in Tridentine Italy: Cardinal Pole and the CounterReformation (Cambridge: Cambridge University Press, 1972), esp.pp. 1-99, provides lucid insights into the complexities of the Italian "evangelical" movement. For two recent studies of the prominent part played by Reginald Pole, see Thomas F. Mayer, Reginald Pole, Prince and Prophet (Cambridge: Cambridge University Press, 2000), pp. 103-74, and "A Reluctant Author: Cardinal Pole and His Manuscripts," Transactions of the American Philosophical Society 89.4 (1999): 1-6.

37. Thomas Becon, The Sicke Man's Salve. Wherein faithful Christians may learne both how to behave themselves paciently and thankfully in tyme of sickness (London: J. Day, 1561), RSTC 1757. Although the work was composed before 1553, Becon was imprisoned until 1554, and this is the earliest extant edition. References are to the version included in The Worckes of Thomas Becon, 3 vols. (London: J. Day, 1563-64), vol. 2, RSTC 1710. For Becon's life see Derrick S. Bailey, Thomas Becon and the Reformation in the Church of England (Edindurgh: Oliver and Boyd, 1952). Other comparable literature translated and printed around the same time includes Otto Werdmueller, A most frutefull, pithye and learned treatise how a christen ma(n) ought to behave himself in danger of death, trans. (anonymously) by Miles Coverdale, which was bound together with An exhortation by the Lady Jane Grey the night before she died ([Wesel: H. Singleton (?), 1555]), RSTC 25251. The translation is reprinted in Miles Coverdale, Remains, ed. George Pearson, Parker Society (Cambridge: Cambridge University Press, 1846), pp. 37-132.

38. Becon, fol. $279 \mathrm{v}$, cited Beaty, p. 115.

39. The Two Liturgies, A.D. 1549 and A.D. 1552, etc., ed. Joseph Ketley, Parker Society (Cambridge: Cambridge University Press, 1844), pp. 136 and 312. Later, even greater religious acumen was expected; these statements of faith were rejected as a soft option by William Perkins, and extempore declaration of individual faith was required instead (Ralph Houlbrooke, "The Puritan Deathbed, c.1560-c.1660," in The Culture of English Puritanism: 1560-1700, ed. Christopher Durston and Jacqueline Eales [Houndmills, Basingstoke, Hampshire: Macmillan, 1996], pp. 122-44, esp. 132).

40. Two Liturgies, p. 136 (1549).

41. Cited Beaty, p. 130.

42. Neighbours could read "devout Histories and devout praiers in which he [the dying man] delyted most when he was in hele" (Tractatus, cited Beaty, p. 28).

43. Helen White, The Tudor Books of Private Devotion (Madison: University of Wisconsin Press, 1951), p. 139; Beaty, pp. 128-30.

44. The Queens College, Oxford Ms. 390, "Diary of Thomas Crossfield," fol. 38v, cited by David Cressy, Birth, Marriage and Death: Ritual, Religion and the Life Cycle in Tudor and Stuart England (Oxford: Oxford University Press, 1997), p. 390; Judith Maltby, Prayer Book and People in Elizabethan and Early Stuart England (Cambridge: Cambridge University Press, 1998), p. 50. 
45. Compare Erasmus's comment on "spiritual friends" at the deathbed: ". . at their last breath so tormented by ignorant fools that they give up the ghost almost in despair" ("The Shipwreck," Colloquies of Erasmus, trans. Craig R. Thompson [Chicago: University of Chicago Press, 1965], pp. 139-46, cited Ariès, p. 303). The problems of the social deathbed had a long history.

46. See, e.g., "The cry of the poor for the Earl of Huntingdon," (1596; rpt. Cressy, p. 391).

47. Becon, fol. $261^{v}-63^{v}$, cited Beaty, p. 148.

48. For the continuation of visions of devils and fear of damnation in Protestantism, see Houlbrooke, "Puritan Deathbed," p. 136; Marshall, who points out that the Protestant objective "was not to restore society to a condition of being at ease with itself" ("Fear, Purgatory and Polemic," p. 161);.David Stannard, The Puritan Way of Death (New York: Oxford University Press, 1977), p. 79; and Bodleian Library, Ms. Top. Camb. E.5, "Diary of William Johnson 1652-63," fol. 57, cited Cressy, p. 392.

49. Becon, fol. 240, cited Beaty, p. 135. This may be partly because the sacraments are not prominent in the Ars Moriendi. Neighbours are advised to get the priest, and he is there prominently in the woodcuts, but it has been suggested that the work was written principally for those who died without the sacraments (John McNeill, A History of the Cure of Souls [New York: Harper, 1951], p. 159, cited Beaty, p. 27; Houlbrooke, "Puritan Deathbed," pp. $124,135)$.

50. Becon, fol. $264-65^{\mathrm{v}}$, cited Beaty, p. 139.

51. Diarmaid MacCulloch, Thomas Cranmer: A Life (New Haven: Yale University Press, 1996), p. 614.

52. Two Liturgies, p. 316 (1552). Peter Martyr Vermigli, one of the Italian reformers invited by Cranmer, influenced the drafting of this rubric. See F. E. Brightman, The English Rite, 2 vols. (London: Rivingtons, 1915), vol. 1, p. cliv, 2: 828, 842-43; Alan Beesley, "An Unpublished Source of the Book of Common Prayer: Peter Martyr Vermigli's 'Adhortatio ad Coenam Domini Mysticam,"' Journal of Ecclesiastical History 19 (1968): 83-88; and Duffy, p. 474.

53. Local sources show that those concerned tried hard to arrange things so that the dying could still have communion (Maltby, pp. 49-50).

54. Wunderli and Broce, p. 265.

55. Two Liturgies, p. 312 (1552).

56. Becon, fol. $264-70^{v}$, cited Beaty, p. 139.

57. Latimer, 1: 425.

58. For comment on the long-term influences of the Spiera story in literature, see Celesta Wine, "Nathaniel Wood's 'Conflict of Conscience,"' PMLA 50 (1935): 661-78; Lily B. Campbell, “'Doctor Faustus': A Case of Conscience," PMLA 67 (1952): 219-39; David Renaker, "Bunyan's Misattribution to Francis Spira of a Remark by Nathaniel Bacon," Notes and Queries ns 25 (1978): 25; and Overell, "Spiera," pp. 634-35. On the appearance of the Spiera tale in popular literature, see Margaret Spufford, Small Books and Pleasant Histories: Popular Fiction and its Readership in Early Modern England (London: Methuen, 1981), p. 207, and Walsham, pp. 86, 326-27.

59. Ralph Houlbrooke, Death, Religion and the Family in England, 1480-1750 (Oxford: Clarendon Press, 1998), p. 154; Cressy, p. 383. A distinct change in the direction of 
predestinarian belief was observable in Burial Service of the 1552 Prayer Book, but it was not complete, as was shown by later protests of the Calvinists (Clare Gittings, Death, Burial and the Individual in Early Modern England [London: Croom Helm, 1984], p. 41).

60. "Neither Purgatory, nor prayer nor any other after helps can be available for the party departed" (Edwin Sandys, Sermons, ed. John Ayre, Parker Society [Cambridge: Cambridge University Press, 1841], pp. 162-63). Cf. Duffy, p. 376; "I commend unto you the souls departed" (Latimer, 1: 217 and 284, cited MacCulloch, p. 509), and Becon, fol. 263v , cited Beaty, pp. 132-33. By contrast, the Spanish were absolutely clear that purgatory would be their destination after death (Carlos Eire, From Madrid to Purgatory [Cambridge: Cambridge University Press, 1995], pp. 251, 520).

61. This idea echoed the ancient sleep of the dead but was different from Luther's sleeping of souls. In this Protestant variation on the sleep motif, the elect soul went to heaven immediately but the body remained in the "dormitory" until the general resurrection; see Cressy, pp. 385-88; David Dymond, "God's Disputed Acre," Journal of Ecclesiastical History 50 (1999): 464-97, esp. 466; and Nicholas Tyacke, "Anglican Attitudes," Journal of British Studies 35 (1996): 139-67, esp. 147. On mature Protestant "rhetorical diffidence" about the destination of the dead, see Peter Marshall, "Geographies of the Afterlife in Tudor and Early Stuart England," in The Place of the Dead: Death and Remembrance in Late Medieval and Early Modern Europe, ed. Bruce Gordon and Peter Marshall (Cambridge: Cambridge University Press, 2000), pp. 110-30, esp. 117. This invaluable collection appeared after the present article was completed.

62. Thomas Cranmer, Certain Sermons or Homilies (1547) and A Homily against Disobedience and Wilful Rebellion (Toronto: University of Toronto Press, 1987), p. 155.

63. Two Liturgies, pp. 142 and 145 (for 1549 Prayer Book) and pp. 317 and 319 (for 1552 Prayer Book); John 5:24.

64. Cressy, p. 388. 